\title{
ANALISA DAN PERANCANGAN PEMINATAN PEMILIHAN MAKANAN DAN MINUMAN DENGAN MENGGUNAKAN ALGORITMA APRIORI
}

\author{
${ }^{1)}$ Herly Nurrahmi ${ }^{2)}$ Gaung Sukma \\ Email: ${ }^{1)}$ herlyrahmi@istn.ac.id ${ }^{2)}$ gaungsukma47@gmail.com \\ ${ }^{1)}$ Program Studi Sistem Informasi, Fakultas Sains Dan Teknologi Informasi \\ 1) 2)Institut Sains Dan Teknologi Nasional
}

\begin{abstract}
ABSTRAK
Perkembangan usaha kedai kopi sampai saat ini berada pada pertumbuhan yang sangat tinggi. Data mining diperlukan dalam penjualan produk pada coffee shop untuk menentukan pola kombinasi makanan dan minuman. Algoritma apriori digunakan pada teknik data mining yang diimplementasikan pada sistem persediaan dengan menggunakan data-data penjualan produk coffee shop sebelumnya. Metode spiral digunakan sebagai metode pengembangan sistem. Bahasa pemrograman PHP digunakan untuk analisa pemilihan makanan dan minuman sedangkan untuk database menggunakan MySQL dan menggunakan Microsoft Visio untuk hasil perancangan program. Aplikasi berbasis web yang dibuat dapat membantu customer dan barista untuk mengetahui produk yang paling diminati dan yang kurang diminati dalam kurun waktu tertentu sehingga bermanfaat dalam proses evaluasi untuk kemajuan dan kenyamanan Barista dan Customer di coffee.
\end{abstract}

Kata Kunci: Coffee Shop, Algoritma Apriori, PHP, Web

\section{PENDAHULUAN}

Aktivitas masyarakat di perkotaan semakin padat seiring dengan berjalannya waktu dan berkembangnya zaman. Hal ini membuat padatnya aktivitas masyarakat sehingga membutuhkan refreshing untuk melepas kepenatan dari aktivitas-aktivitas yang dilakukan. Salah satu kegiatan yang dapat melepas kepenatan masyarakat adalah seperti berkumpul di kafe bersama keluarga ataupun bersama rekan-rekan.

Salah satu bisnis yang menyediakan olahan kopi dan teh sebagai menu utama adalah kedai kopi/Coffee shop. cita rasa yang enak serta cara pembuatan dan penyajian kopi yang berbeda-beda dapat didapatkan oleh para pencinta kopi. Salah satu pertimbangan konsumen dalam memilih kedai kopi/Coffee shop adalah karena menu yang berkualitas dan suasana kafe yang nyaman [1].

Di beberapa kota besar di Indonesia banyak kedai kopi atau istilah lainnya coffee shop. Salah satu kedai kopi/ coffee shop yang terkenal dengan berbagai menu bercita rasa kopi berada di Jakarta adalah Coffee shop tolu. Usaha coffee shop tolu dari awal buka mengalami perkembangan yang sangat tinggi. Hal tersebut mengindikasi bahwa coffee shop tolu telah mampu memberi kepuasan kepada pelanggannya dan tercermin dari semakin meningkatnya tingkat kunjungan pelanggan dari waktu ke waktu. Atas dasar fenomena di atas peneliti menganalisa produk yang paling diminati pelanggan dari tingkat kunjungan yang terus mengalami peningkatan pada coffe shop tolu, yaitu dengan menganalisa data penjualan, strategi produk, harga produk, promosi dan tempat terhadap produk-produk yang paling banyak diminati pada coffee shop tolu.

Untuk menemukan pola frekuensi tinggi algoritma yang dapat digunakan adalah Algoritma apriori dimana pada algoritma apriori dibagi menjadi beberapa tahap yang disebut naration atau pass.

1) Pembuatan candidat item set, candidat k-itemset dibuat dengan penggabungan (k-1)-itemset yang diperolah pada iteration sebelumnya. Salah satu upaya pada algoritma apriori yakni pemotongan candidat k-itemset dimana subsetnta terdiri dari k-1 item yang tidak masuk frekuensi tinggi pattern yang mempunyai panjang sebesar k-1.

2) Estimasi support untuk setiap candidat k-itemset. Support untuk setiap candidat pada k-itemset diperoleh dengan scan basis data yang bertujuan menghitung total transaksi yang memadati item dalam k-item set. Hal ini merupakan ciri pada algoritma apriori yang membutuhkan estimasi dengan semua basis data dengan $\mathrm{k}$-item set terpanjang. 
3) Pembuatan pattern frekuensi tinggi. Pattern pada frekuensi tinggi memadati k-item yang ditperoleh dari candidat $\mathrm{k}$-item set yang nilai support nya lebih tinggi dari nilai minimum support.

4) Jika tidak didapatkan pattern frekuensi tinggi maka semua proses diberhentikan. Jika proses tidak dihentikan makan $\mathrm{k}$ akan ditambah 1 yang akan kembali pada bagian 1. [2]

Salah satu Teknik dalam data mining untuk menemukan rule assosiatif setiap kombinasi item dapat menggunakan Association rule. Salah satu model aturan asosiatif pada anlisis pembelian pada pasar swalayan yakni dapat mengetahui suatu peluang seseorang membeli roti dalam waktu yang sama dengan pembelian susu. Dengan menggunakan knowledge ini owner pasar swalayan tersebut bisa mengelompokkan penempatan produk atau merancangan pemasaran menggunakan diskon pada kombinasi produk tertentu. Analisa assosiatif ini diingat sebagai Teknik data mining yang menjadi dasar untuk Teknik-teknik data mining lainnya. [2]

Pada penelitian yang dibuat oleh Wisnu Dwi Atmojo yang berjudul sistem pakar minat bakat atlet baru pada mata lomba aeromodeling dengan menggunakan metode certainty factor. Pada aplikasi ini para atlet aeromodeling dapat memilih mata lomba yang sesuai dengan kriteria dalam diri atlet agar dapat mendalami mata lomba yang telah disarankan. Penelitian ini bertujuan untuk menentukan jenis minat dan bakat yang didasarkan oleh ciri-ciri dengan menggunakan certaintly factor. Hal tersebut dapat digunakan sebagai pilihan di dalam perhitungan minat dan bakat. Hasil dari penelitian ini adalah sistem dapat menentukan jenis minat dan bakat pada atlet-atlet baru dari mata lomba aeromodelling yang disasarkan pada ciri-ciri yang telah dipilih oleh pengguna. [3]

\section{METODE PENELITIAN}

Dalam penelitian ini metode yang digunakan yaitu metode spiral yang bisa dilihat pada gambar di bawah ini dan dengan proses adalah sebagai berikut [4]:

1) Komunikasi Pelanggan / customer communication. Proses ini dibutuhkan terutama untuk kebutuhan pelanggan membangun komunikasi yang efektif.

2) Perencanaan. Aktivitas perencanaan ini dibutuhkan untuk menentukan sumber daya, perkiraan waktu pengerjaan, dan informasi lainnya yang dibutuhkan untuk pengembangan software.

3) Analisis Resiko. Pada Aktivitas ini digunakan untuk menganalisis resiko teknikal dan manajerial. Pada aktivitas ini menggunakan metode iterasi.

4) Engineering. Pada proses ini bertujuan untuk mengembangkan 1 atau lebih representasi dari aplikasi dengan cara teknikal.

5) Construction \& Release. Pada proses ini dibutuhkan pengembangan software, pengujian, installation dan penyediaan penggunaan seperti pelatihan penggunaan software ataupun buku petunjuk manual software.

6) Evaluasi Pelanggan. Proses evaluasi pelanggan ini dilakukan untuk mendapatkan feedback dari pengguna dari evaluasi software pada tahap engineering dan juga pada tahapan implementasi installation software di proses construction dan release.

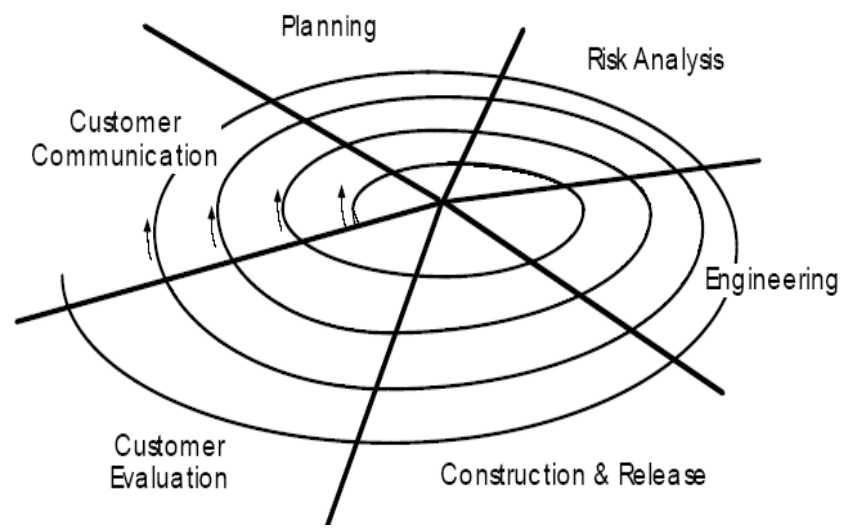

Gambar 1. Metode Pengembangan Sistem Spiral 


\section{HASIL DAN PEMBAHASAN}

\subsection{Page (halaman) Masuk Administrator}

Pada pagi ini menampilkan halaman masuk admin yang berguna untuk masuk ke dalam beranda. Dalam tampilan halaman ini, jika ingin login harus mengisi username dan password. Untuk tampilan page (halaman) masuk administrator terlihat pada gambar 2 di bawah ini:

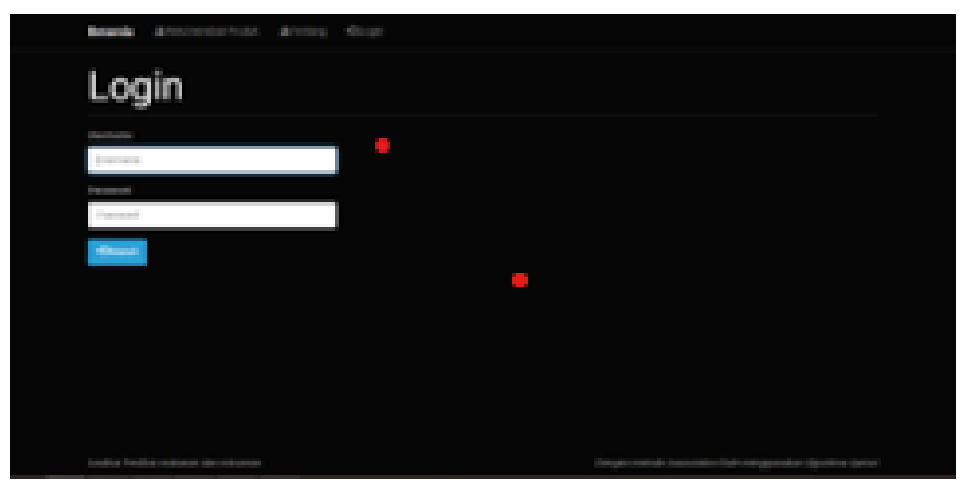

Gambar 2. Halaman Login Admin

\subsection{Page (Halaman) Beranda Menu Admin}

Pada Halaman ini menampilkan tampilan awal pada menu Admin setelah melakukan proses login Admin. Di dalam tampilan ini terdapat data transaksi, stock, perhitungan apriori, ubah password dan logout. Tampilan main page terlihat pada gambar 3 di bawah ini:

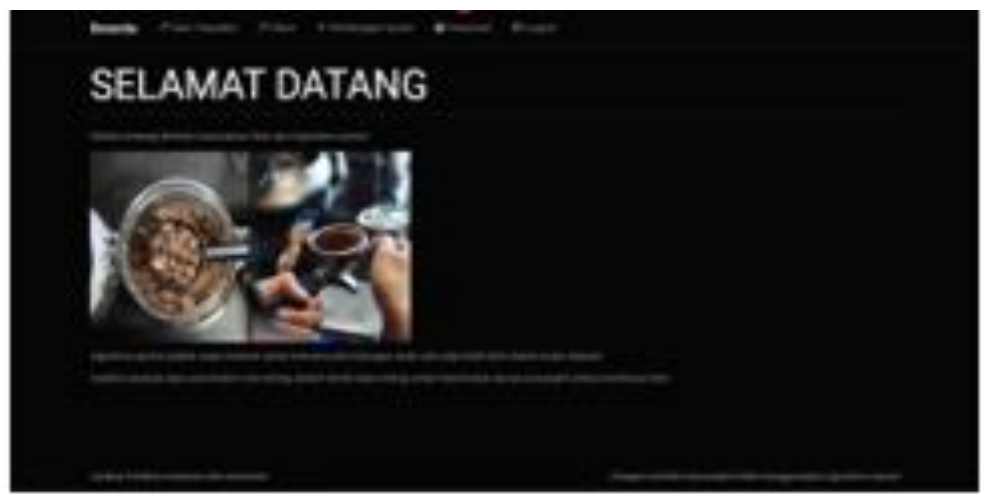

Gambar 3. Halaman Beranda Admin

\subsection{Page (Halaman) Transaksi Pada Menu Admin}

Di dalam page (halaman) transaksi pada menu ini, Administrator dapat melakukan CRUD. Di dalam tampilan ini admin dapat mencari transaksi, refresh transaksi, menambah transaksi, impor transaksi, cetak transaksi dan kosongkan transaksi. Tampilan Halaman data Produk dapat terlihat dari gambar 4 di bawah ini:

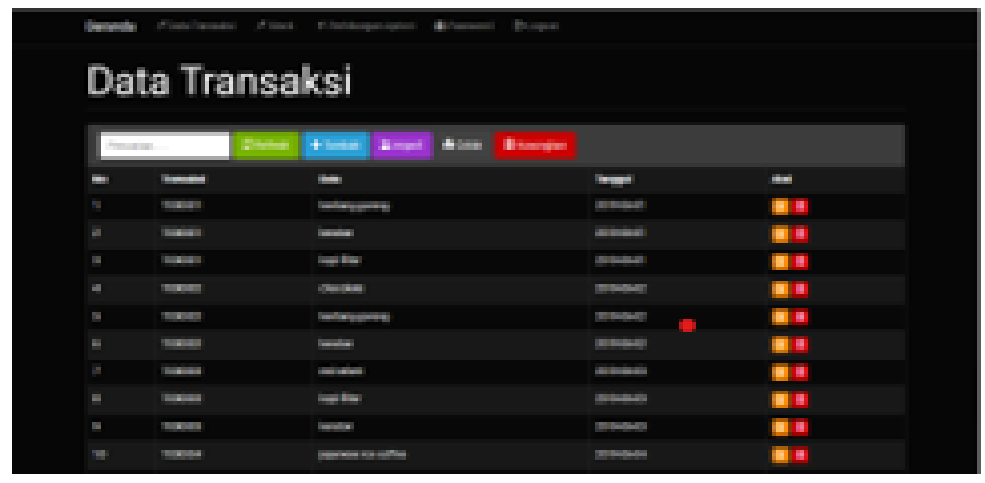

Gambar 4. Halaman Data Produk 


\subsection{Halaman Perhitungan Apriori}

Page (halaman) perhitungan apriori digunakan untuk menghitung hasil akhir berdasarkan produk, dengan cara memasukkan date transaksi awal, date transaksi akhir, nilai minimal support dan nilai minimal confidence. Tampilan Halaman perhitungan apriori terlihat pada gambar 5 di bawah ini:

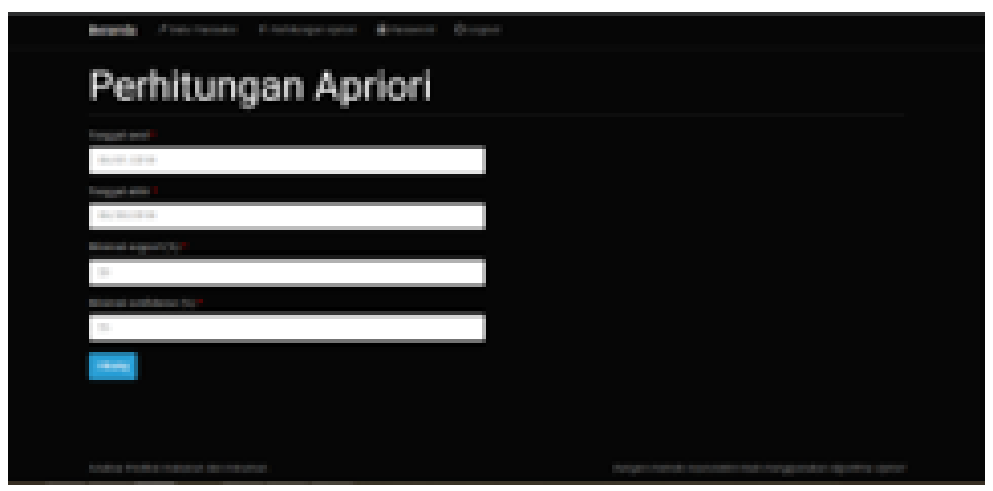

Gambar 5. Halaman Perhitungan Apriori

\subsection{Page (halaman) Perhitungan Apriori}

Pada halaman perhitungan apriori ini merupakan page (halaman) yang menampilkan perhitungan akhir apriori. Di tampilan hasil akhir ini terdapat kandidat 1 itemset, kandidat 2 itemset dan pembentukan asosiasi 2 itemset. Interface page (halaman) akhir dari perhitungan apriori terlihat pada Gambar 6 di bawah ini:



Gambar 6. Halaman Login Admin

Gambar 6. Halaman Perhitungan Apriori

\subsection{Page (halaman) Stock Pada Menu Admin}

Halaman Stock ini digunakan untuk mengetahui jumlah stock produk berdasarkan hasil akhir perhitungan. Di dalam tampilan ini terdapat hasil prediksi dan foto produk. Tampilan Halaman stock produk terlihat pada gambar 7 di bawah ini:

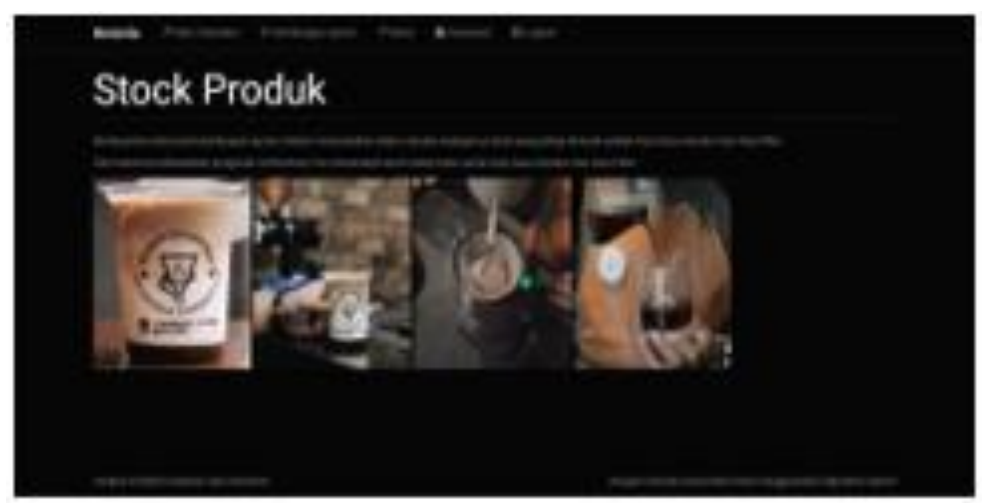

Gambar 7. Halaman Stock

\subsection{Page (halaman) Ubah Password}

Tampilan hasil dan solusi konsultasi ini ditampilkan tepat di bawah halaman hasil konsultasi pada menu atlet, terlihat pada gambar 8 di bawah ini: 


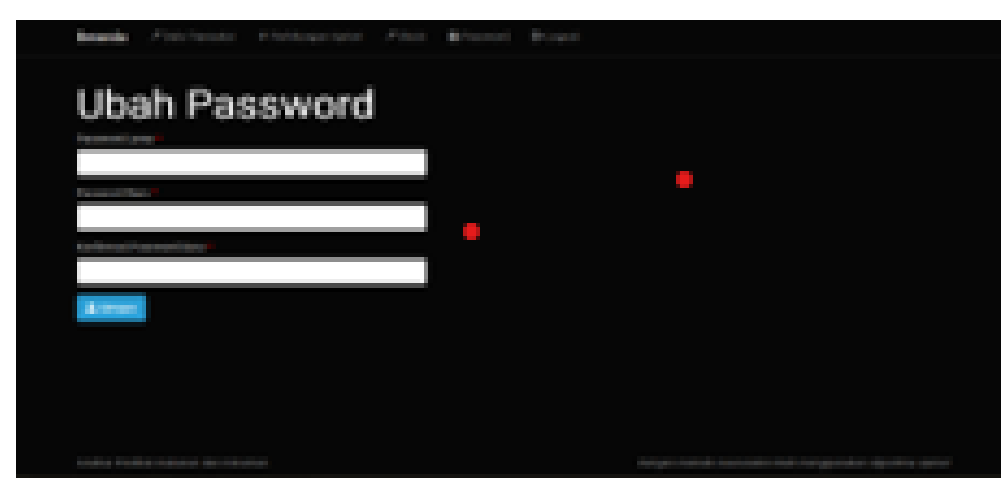

Gambar 8. Halaman Ubah Password

\subsection{Page (halaman) Beranda Pada Menu User}

Pada Halaman ini menampilkan tampilan awal pada menu User setelah melakukan proses login User. Di dalam tampilan ini terdapat rekomendasi produk serta profil. Interface main page (halaman utama) terlihat dari gambar 9 di bawah ini:

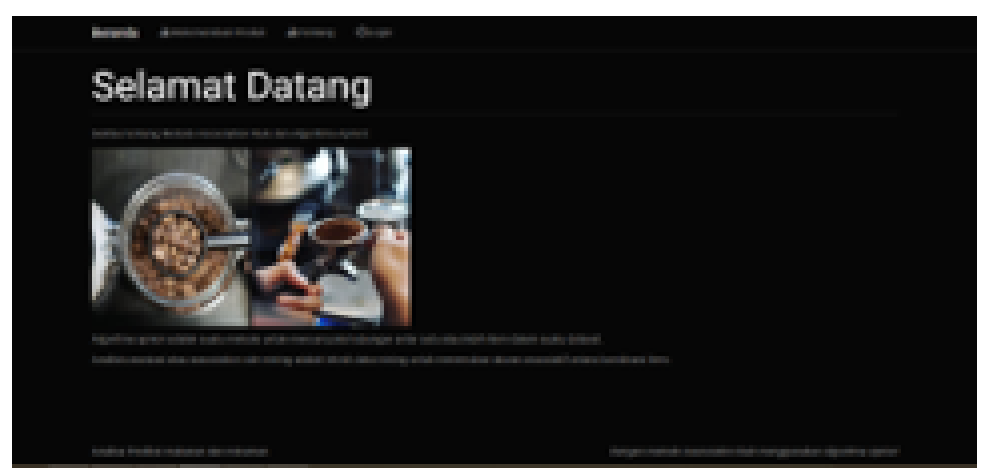

Gambar 9. Halaman Beranda Menu User

\subsection{Page (halaman) Rekomendasi Produk Pada Menu User}

Halaman rekomendasi produk bertujuan untuk memberi info kepada customer tentang rekomendasi menu yang paling banyak diminati. Di dalam tampilan ini terdapat foto dan produk yang jadi rekomendasi. Tampilan halaman rekomendasi produk terlihat pada gambar 10 di bawah ini:

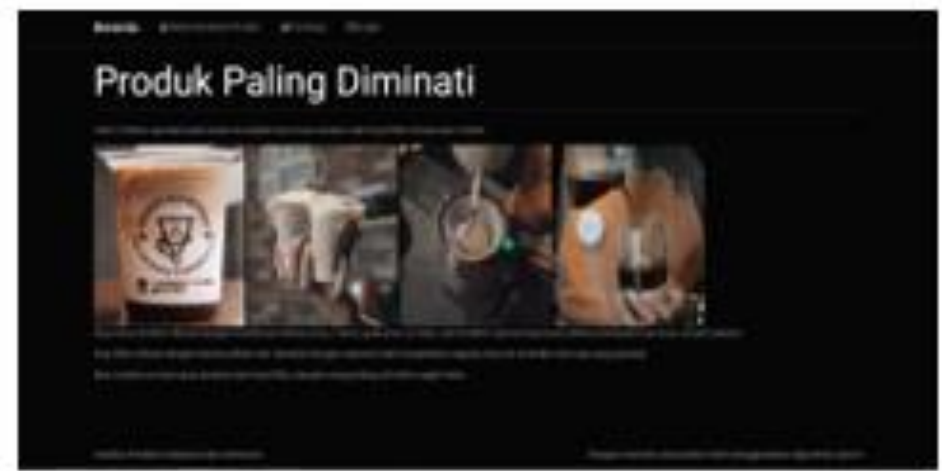

Gambar 10. Halaman Rekomendasi Produk

\subsection{Halaman Profil Pada Menu User}

Halaman Tentang bertujuan untuk memberi info kepada customer tentang profil Tolu Coffee. Di dalam tampilan ini terdapat info dan alamat Tolu Coffee. Interface profile tentang coffe shop terlihat pada gambar 11 di bawah ini: 


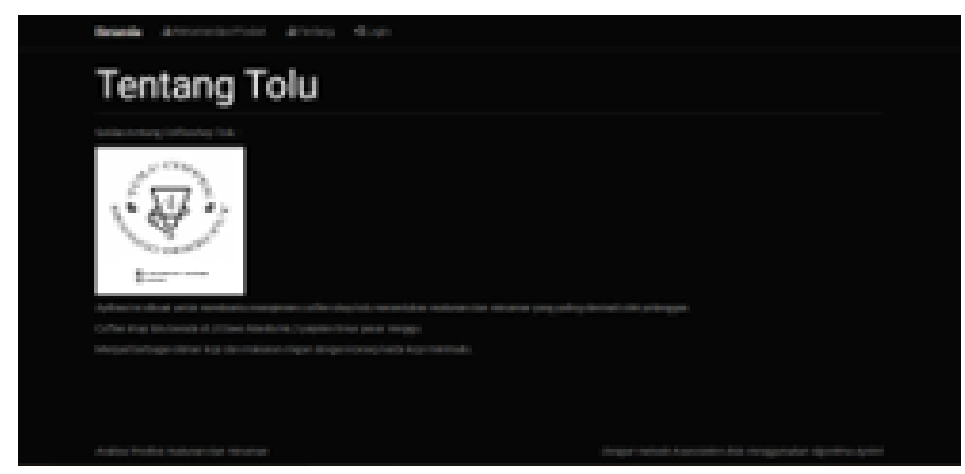

Gambar 11. Halaman Profil Coffee Shop

\section{KESIMPULAN}

Adapun kesimpulan pada penelitian ini yakni:

1) Pada penjualan produk pada Coffee Shop Tolu untuk menentukan pola kombinasi produk makanan dan minuman dibutuhkan Teknik data mining. Teknik data mining yang digunakan yakni algoritma apriori dan diimplementasikan pada sistem persediaan dengan menggunakan sales data sebelumnya.

2) Analisa pemilihan peminatan Makanan dan Minuman ini dibuat dengan bahasa pemrograman PHP, database menggunakan MySQL dan hasil perancangan program menggunakan Microsoft Visio. Aplikasi berbasis web yang dibuat dapat membantu customer dan barista untuk mengetahui produk yang paling diminati dan yang kurang diminati dalam kurun waktu tertentu sehingga bermanfaat dalam proses evaluasi untuk kemajuan dan kenyamanan Barista dan Customer di coffee shop Tolu.

3) Berdasarkan volume data dan level confidence serta support yang bervariasi sehingga banyaknya asosiasi setiap data dan pola kombinasi dan rules semakin akurat.

\section{DAFTAR PUSTAKA}

Donal, A. 2016. Analisis Pengaruh Kualitas Produk dan Suasana Kafe (Cafe Atmosphere) Terhadap Keputusan Pembelian Pada Kedai Kopi (Coffee Shop) Kubik Koffie Padang. Tesis. Universitas Andalas. [1]

Buulolo, E. 2010. Association Rules. Dikutip Dalam Jurnal Implementasi Persediaan Obat. [2]

Wisnu Dwi Atmojo. 2018. Sistem Pakar Minat Bakat Atlet Baru Pada Mata Lomba Aeromodelling Dengan Menggunakan Metode Certainty Factor [3]

Sommerville Ian. 2013. Software Engineering. Pearson [4] 